\title{
BRIEF COMMUNICATION \\ Effects of seawater temperature on sound characteristics in Ophidion rochei (Ophidiidae)
}

\author{
L. Kéver*†, K. S. Boyle $\$$ And E. Parmentier* \\ *Laboratoire de Morphologie Fonctionnelle et Evolutive, AFFISH-RC, Institut de Chimie, Bât. \\ B6c, Université de Liège, B-4000 Liège, Belgium and $\ddagger$ Département d'Ecologie et de Gestion \\ de la Biodiversité, Muséum National d'Histoire Naturelle, 57 rue Cuvier, Case postale 55, \\ 75231, Paris Cedex 5, France
}

(Received 19 November 2014, Accepted 19 May 2015)

\begin{abstract}
Although the sound production mechanisms of male and female Ophidion rochei (Ophidiidae) differ significantly, temperature affects them in the same manner. In both sexes, temperature correlated negatively with pulse period and positively with sound frequencies but had no, or weak effects on other sound characteristics.
\end{abstract}

(C) 2015 The Fisheries Society of the British Isles

Key words: acoustic; communication; fish; Ophidiiformes.

The suborder Ophidioidei (Ophidiidae and Carapidae) contains more than 200 species (Nielsen et al., 1999). All species investigated in this taxon show distinctive and complex sonic apparatuses based on extrinsic sonic muscles that insert directly or indirectly on the swimbladder wall (Rose, 1961; Courtenay \& McKittrick, 1970; Courtenay, 1971; Parmentier et al., 2003; Fine et al., 2007). Unfortunately, studies describing sound characteristics in Ophidioidei are limited to two ophidiids (Mann et al., 1997; Kéver et al., 2012) and five carapids (Parmentier et al., 2003, 2006) mainly because the majority of species are quite inaccessible. The way environmental factors affect these sounds is even less documented and is limited to three studies. The first suggested that seawater temperature affects sounds recorded in the field attributed to Ophidion marginatum Dekay 1842 (Sprague \& Luczkovich, 2001), the second showed that the sounds of carapids are negligibly affected by the tegument of their sea cucumber hosts (Parmentier et al., 2006) and the third reported sound amplification by the host (pearl oyster) cavity in the carapid Onuxodon fowleri (Smith 1955) (Kéver et al., 2014a).

Because fishes are poikilotherms, the activity of the neuromotor system depends on temperature (Walker, 1975). Generally, higher water temperatures increase the contraction rate of sound production muscles (Demski et al., 1973; Feher et al., 1998). Effects of this relationship on sounds were described in a few species (Fine, 1978;

†Author to whom correspondence should be addressed. Tel.: +3243665033; email: Loic.Kever@ulg.ac.be 
Connaughton et al., 2000; Sprague \& Luczkovich, 2001; Papes \& Ladich, 2011). In weakfish Cynoscion regalis (Bloch \& Schneider 1801), higher temperatures increase pulse rate, call intensity and dominant frequency of sounds (Connaughton et al., 2002). Similar effects were observed for sounds of Opsanus tau (L. 1766) (Fine, 1978), O. marginatum (Sprague \& Luczkovich, 2001) and Platydoras armatulus (Valenciennes 1840) (Papes \& Ladich, 2011).

During the puberty of Ophidion rochei Müller 1845, the sonic apparatus becomes highly modified in males but not in females (Kéver et al., 2012). Adult males but not females have a mineralized structure called the rocker bone at the anterior end of their swimbladder. They also have larger sonic muscles and swimbladder plates (modified epineurals in association with the swimbladder) than females. Modifications of the male sonic apparatus during sexual maturation are related to important modifications in sound characteristics (Kéver et al., 2014b) and the sexual dimorphism in the sound production mechanism of $O$. roche $i$ has been associated with completely distinct sound types (Kéver et al., 2012): long and pulsed sounds in males, and short and more tonal sounds in females (Fig. 1). Male calls show a unique pattern: the pulse period increases through the first several pulses, then it alternates between long and short durations in successive pulses (Parmentier et al., 2010; Kéver et al., 2012). The aim of this study was to describe the effects of seawater temperature on the different $O$. rochei sound characteristics.

In $O$. rochei, the reproductive period lasts from June to September (Jardas, 1996). Sounds were recorded at night in May 2010, July 2010 (Kéver et al., 2012), September 2008 (Parmentier et al., 2010) and September 2011 in Duće-Glava (Croatia) at $2 \mathrm{~m}$ depth. The water temperatures were $13.5,21 \cdot 5,23.5$ and $25^{\circ} \mathrm{C}$, respectively. A few additional male calls were recorded from 9 to 10 August 2010 in Banyuls-sur-mer (France) at $27 \mathrm{~m}$ depth with the temperature $17 \cdot 5^{\circ} \mathrm{C}$. Recordings were made with a digital spectrogram long-term acoustic recorder (DSG, Loggerhead Instruments; www.loggerhead.com). This hydrophone $\left(-186 \mathrm{~dB}\right.$ re $\left.1 \mathrm{~V} \mathrm{\mu Pa}^{-1}\right)$ was programmed to record $10 \mathrm{~min}$ per half hour during night-time at a sample rate of $20000 \mathrm{~Hz}$.

Sounds were analysed in Avisoft SAS-Lab Pro 4.5 using the semi-automatic method described and used in previous studies (Kéver et al., 2012, 2014b). Sounds were recorded from both sexes but it was not possible to identify the sound producer because the fish were active in the dark (Matallanas \& Riba, 1980). For female sounds, pulse number, pulse duration (duration from beginning to the end of a pulse, ms), pulse period (duration from the beginning of a pulse to the beginning of the next one, $\mathrm{ms})$, fundamental frequency $(\mathrm{Hz})$ and the first two harmonics were measured. The following variables were collected from male sounds: pulse number, pulse duration, alternation start (the pulse number when the pulse period alternation pattern was initiated), short pulse period (short pulse periods after the alternation start, ms), long pulse period (long pulse periods after the alternation start, ms) and the two peak frequencies $(\mathrm{Hz})$. Because sounds contained many pulses, variables such as pulse duration and pulse periods (short and long pulse periods in males) were measured whenever possible. Then, data were averaged in order to obtain one value per sound.

Linear regressions were chosen to describe the effects of temperature on sound characteristics because they provided a better fit to observations than non-linear regressions. Regression lines were produced with Graphpad Prism 5 (Graphpad Software, Inc.; www.graphpad.com). The data of all variables were $\log _{10}$ transformed and the normal distribution of data and regression residuals was verified. 

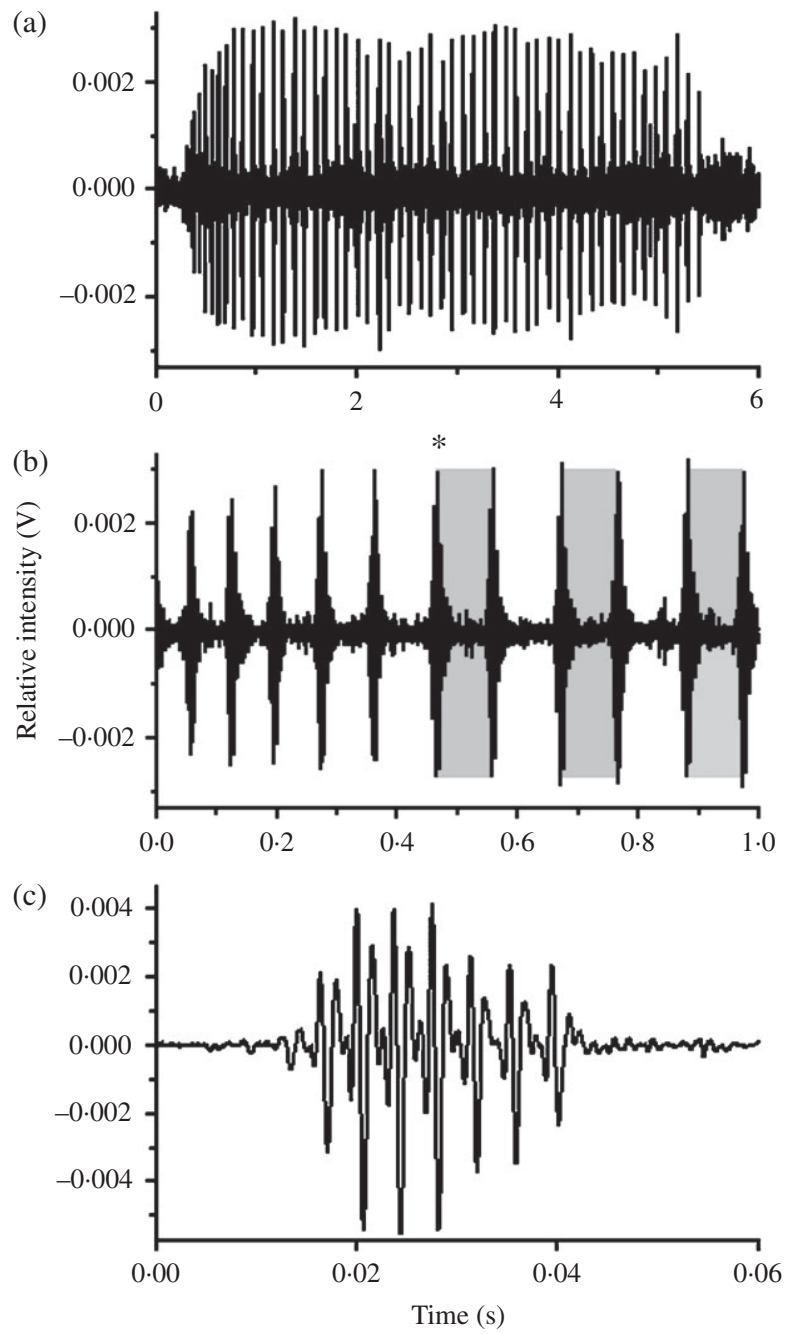

FIG. 1. Waveforms of two Ophidion rochei calls recorded in July 2010 in Duće-Glava (Croatia). (a) Waveform of a multiple-pulsed sound of a male O. rochei. (b) Zoom in (pulses 6-16) on the waveform of the call shown in (a). (c) Waveform of a sound of a female $O$. rochei. $*$, alternation start;, , first three short pulse periods of the male call.

In females, the slopes for pulse duration and pulse number against temperature did not differ from zero [Fig. 2(a), (b)]. On the other hand, pulse period and sound frequencies were strongly correlated with temperature $\left(r^{2}>0 \cdot 8\right)$ : pulse period correlated negatively with temperature, whereas the fundamental frequency and related harmonics were positively correlated with this factor [Fig. 2(c), (d)].

In males, alternation start and pulse number [Fig. 3(a), (b)] were negatively (although weakly) correlated with temperature: the alternation start happened later in the call and pulse number was higher at lower temperatures [Fig. 3(a), (b)]. Short and long pulse periods decreased with seawater temperature $\left(r^{2} \geq 0.83\right)$ [Fig. 3(c), (d)] while the first and second peak frequency increased $\left(r^{2} \geq 0 \cdot 73\right)$ with temperature [Fig. 3(e), (f)]. Note, 


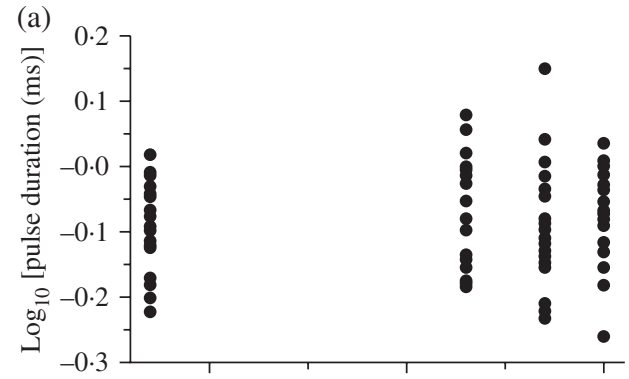

(c)

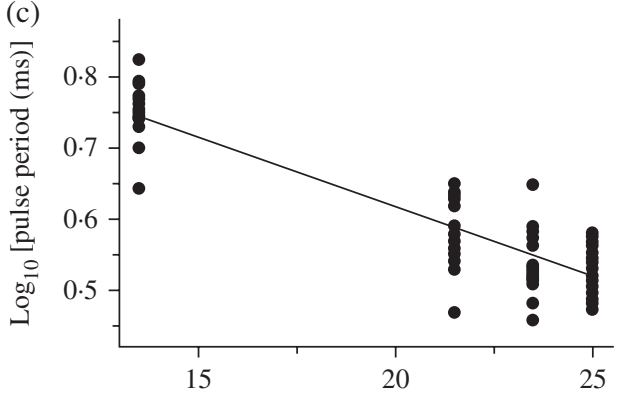

(b)

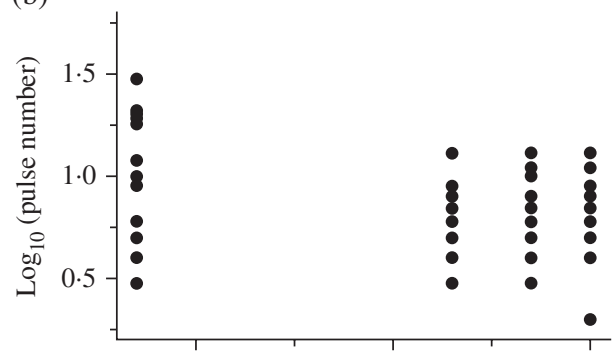

(d)

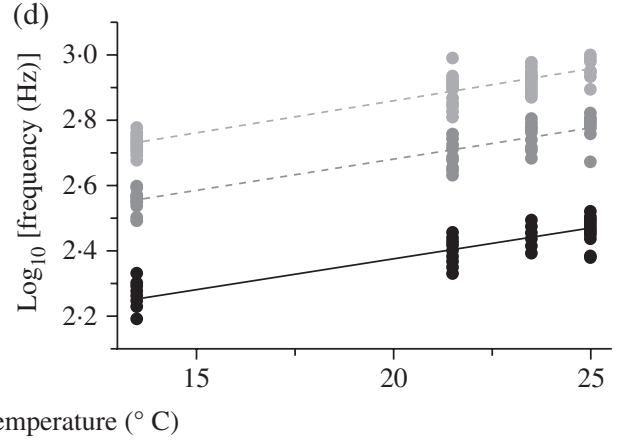

FIG. 2. Influence of temperature on acoustic variables in female Ophidion rochei. (a) Pulse duration (number of sounds, $\left.n=81, r^{2}<0 \cdot 01, P>0 \cdot 05\right)$, (b) pulse number $\left(n=81, r^{2}=0 \cdot 04, P>0 \cdot 05\right)$, (c) pulse period $(n=81$, $\left.r^{2}=0 \cdot 86, P<0 \cdot 01\right)$ and (d) fundamental frequency $\left(n=74, r^{2}=0 \cdot 84, P<0 \cdot 01\right)$ and first two harmonics (first harmonic: $n=77$ and second harmonic: $n=76$ ) and seawater temperature. Results are expressed as mean value for each sound. The curves were fitted by: (c) $y=-0.020 x+1.008$ and (d) $y=0 \cdot 019 x+1.997$ for fundamental frequency, $y=0 \cdot 019 x+2 \cdot 297$ for the first harmonic and $y=0 \cdot 020 x+2 \cdot 467$ for the second harmonic. The three frequencies in (d) are displayed on the same graph but harmonics were represented by to facilitate visualization.

however, that the results for second peak frequency should be considered with caution. Although the slope significantly differed from zero, it was the only variable for which residuals of the linear regression did not show a normal distribution (D'agostino \& Pearson, $P>0 \cdot 05)$. In this particular case, the linear regression is not appropriate to describe the variations in the data. It could result not only from obstacles in sample analysis (e.g. background noise in the field probably impairs the analysis in some frequency bands) but also from the contribution of factors other than temperature to the variability [e.g. second peak frequency is highly affected by fish morphology (Kéver et al., 2014b)]. Despite the difference in the recording depth, second peak frequency of fishes from Banyuls-sur-mer fit relatively well with the regression line based on fish from Duće while the first peak frequency was higher [Fig. 3(e), (f)]. The pulse period was also longer in Banyuls-sur-mer [Fig. 3(c), (d)].

In both sexes, temperature increases were associated with shorter pulse periods and higher frequencies. The significant effect of temperature on sound pulse period and frequency has been shown in other teleosts (Fine, 1978; Connaughton et al., 2000; Papes \& Ladich, 2011). In poikilotherms, higher temperatures increase rates of sonic muscle contractions (Rome \& Lindstedt, 1998) and neural motor activity (Walker, 1975). Walker (1975) showed also that the results from linear regressions fit better than $Q_{10}$ 
(a)

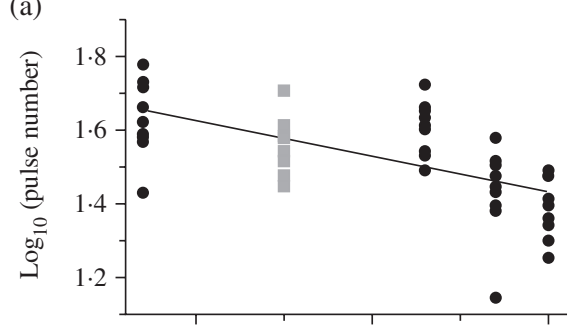

(c)

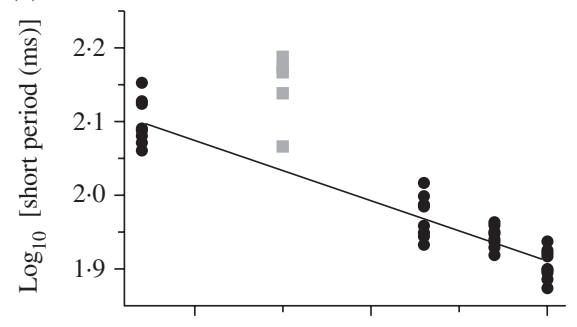

(e)

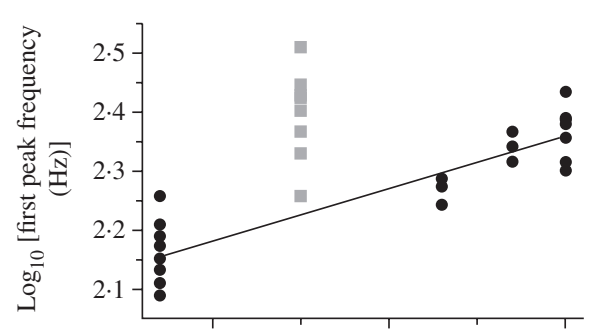

(g)

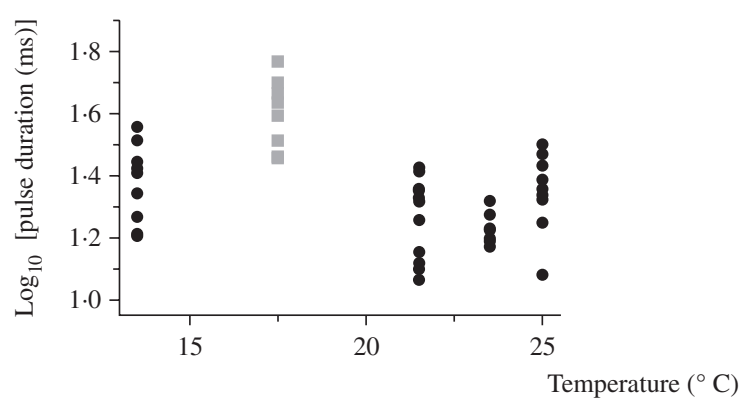

(b)

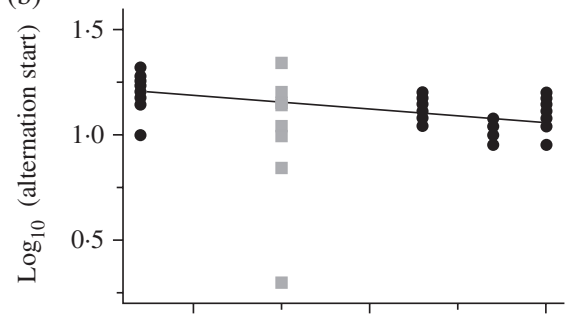

(d)

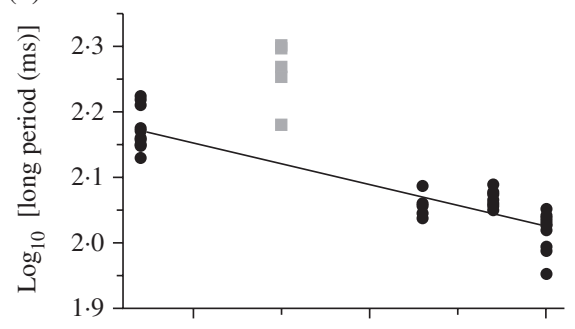

(f)

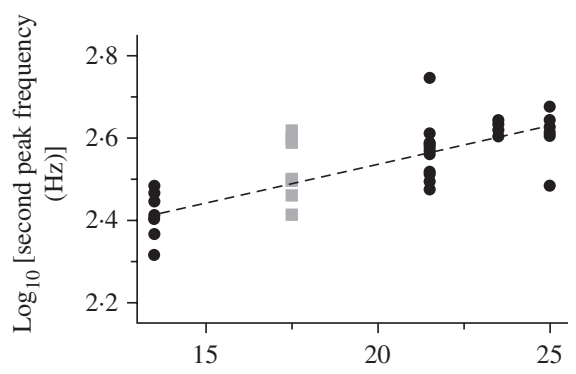

FIG. 3. Influence of temperature on acoustic variables in male Ophidion rochei. (a) Pulse number (number of sounds, $\left.n=44, r^{2}=0 \cdot 38, P<0 \cdot 01\right)$, (b) number of the alternation start pulse $\left(n=44, r^{2}=0 \cdot 38, P<0 \cdot 01\right)$, (c) short pulse period $\left(n=44, r^{2}=0 \cdot 90, P<0 \cdot 01\right)$, (d) long pulse period $\left(n=44, r^{2}=0 \cdot 83, P<0 \cdot 01\right)$, (e) first peak frequency $\left(n=44, r^{2}=0.84, P<0 \cdot 01\right)$, (f) second peak frequency $\left(n=40, r^{2}=0 \cdot 73, P<0 \cdot 01\right)$ and (g) pulse duration $\left(n=44, r^{2}=0 \cdot 07, P>0.05\right)$ and seawater temperature. Field data are from Duće-Glava (Croatia; $\bullet$ ) and Banyuls-sur-mer (France; $\square$ ). Results are expressed as mean value for each sound. The regression line for the second peak frequency is dashed (_ _ . ) because the distribution of the residuals was not normal (D'agostino \& Pearson, $P>0 \cdot 05$ ). The curves were fitted by: (a) $y=-0 \cdot 019 x+1.913$, (b) $y=-0 \cdot 013 x+1 \cdot 391$, (c) $y=-0 \cdot 016 x+2 \cdot 315$, (d) $y=-0 \cdot 013 x+2 \cdot 243$, (e) $y=0 \cdot 018 x+1 \cdot 914$ and (f) $y=0 \cdot 019 x+2 \cdot 157$. 
values to describe a variety of temperature functions. The present results are in full agreement with these previous observations.

According to anatomical and physiological data (Kéver et al., 2012, 2014c), female sounds are produced by fast successive contractions of sonic muscles as in toadfishes (Fine et al., 2001) or piranhas (Millot et al., 2011). In this case, muscle contraction rate corresponds to pulse period and determines the frequency of swimbladder wall vibration, fixing the fundamental frequency of the sound (Fine et al., 2001; Millot et al., 2011). Higher temperature increases activation rate and muscle contraction speed in female $O$. rochei, shortening pulse period and increasing sound dominant frequency.

In males, pulse period also decreased with increasing temperature, meaning the muscle contraction rate increased. Although peak frequency increased with temperature, sound frequency is independent from contraction rate in male calls for at least two reasons: the fundamental frequency $(c .250 \mathrm{~Hz})$ does not match with the pulse period (c. $100 \mathrm{~ms}$ ) and dominant frequency is constant throughout the call despite differences in pulse period within a call (Parmentier et al., 2010). Sonic muscle hypertrophy during the spawning period has been reported in different fish species such as $C$. regalis (Connaughton \& Taylor, 1994; Connaughton et al., 1997), haddock Melanogrammus aeglefinus (L. 1758) (Templeman \& Hodder, 1958) and cod Gadus morhua L. 1758 (Rowe \& Hutchings, 2004). This kind of modification has not yet been shown in $O$. rochei but it was the case in the related ophidiid Lepophidium profundorum (Gill 1863) (Nguyen et al., 2008), which has a slightly different sound-producing mechanism (Fine et al., 2007). Thus, the increase in peak frequency of male sounds is more likely related to contraction speed (i.e. duration of a contraction-relaxation cycle) and force (i.e. sonic muscle hypertrophy) rather than the contraction rate (i.e. pulse period of the call) of the sonic muscle. The increase in peak frequency could also be due to the dilation of the gas: more tension in the swimbladder tissues could result in shorter-amplitude movements (Parmentier et al., 2003).

Finally, male and female sounds recorded at each temperature are impressively variable with many measurements varying over several folds. The variability in the calls recorded may reflect interindividual differences in which case they can potentially be used by the listening fish to differentiate nearby individuals. The variability in some sound characteristics could also be due to differences in caller motivation. Mann \& Lobel (1998) argued that changes in motivation likely explain why Dascyllus albisella Gill 1862 emits sounds composed of fewer pulses against heterospecifics than conspecifics. Because pulse number was shown to vary among calls emitted by a single male $O$. rochei (Kéver et al., 2014b), it is more likely affected by punctual changes in motivation.

Y.-E. Corbisier, B. Dragičević, J. Dulčić, R. Grgičević, P. Romans and D. Fransolet kindly helped during field campaigns. This study was supported by grants from the FRIA (F.R.S.-FNRS) and by a grant from Fonds de la Recherche Fondamentale Collective (FRFC) (number 2.4.535.10.F) delivered by the Belgian National Fund for Scientific Research.

\section{References}

Connaughton, M. A. \& Taylor, M. H. (1994). Seasonal cycles in the sonic muscles of the weakfish, Cynoscion regalis. Fishery Bulletin (Seattle) 92, 697-703.

Connaughton, M. A., Fine, M. L. \& Taylor, M. H. (1997). The effects of seasonal hypertrophy and atrophy on fiber morphology, metabolic substrate concentration and sound characteristics of the weakfish sonic muscle. Journal of Experimental Biology 200, 2449-2457. 
Connaughton, M. A., Taylor, M. H. \& Fine, M. L. (2000). Effects of fish size and temperature on weakfish disturbance calls: implications for the mechanism of sound generation. Journal of Experimental Biology 203, 1503-1512.

Connaughton, M. A., Fine, M. L. \& Taylor, M. H. (2002). Review. Weakfish sonic muscle: influence of size, temperature and season. Journal of Experimental Biology 205, 2183-2188.

Courtenay, W. R. (1971). Sexual dimorphism of the sound producing mechanism of the striped cusk eel, Rissola marginata (Pisces: Ophidiidae). Copeia 1971, 259-268.

Courtenay, W. R. \& McKittrick, F. A. (1970). Sound-producing mechanisms in carapid fishes, with notes on phylogenetic implications. Marine Biology 7, 131-137.

Demski, L. S., Gerald, J. W. \& Popper, A. N. (1973). Central and peripheral mechanisms of teleost sound production. American Zoologist 13, 1141-1167.

Feher, J. J., Waybright, T. D. \& Fine, M. L. (1998). Comparison of sarcoplasmic reticulum capabilities in toadfish (Opsanus tau) sonic muscle and rat fast twitch muscle. Journal of Muscle Research and Cell Motility 19, 661-674.

Fine, M. L. (1978). Seasonal and geographical variation of the mating call of the oyster toadfish Opsanus tau L. Oecologia 36, 45-57.

Fine, M. L., Malloy, K. L., King, C. B., Mitchell, S. L. \& Cameron, T. M. (2001). Movement and sound generation by the toadfish swimbladder. Journal of Comparative Physiology A 187, 371-379.

Fine, M. L., Hsung, L., Nguyen, B. B., Rountree, R. A., Cameron, T. M. \& Parmentier, E. (2007). Functional morphology of the sonic apparatus in the fawn cusk-eel Lepophidium profundorum (Gill, 1863). Journal of Morphology 268, 953-966.

Jardas, I. (1996). Jadranska ihtiofauna. Zagreb: Skolska knjiga.

Kéver, L., Boyle, K. S., Dragičević, B., Dulčić, J., Casadevall, M. \& Parmentier, E. (2012). Sexual dimorphism of sonic apparatus and extreme intersexual variation of sounds in Ophidion rochei (Ophidiidae): first evidence of a tight relationship between morphology and sound characteristics in Ophidiidae. Frontiers in Zoology 9, 1-16.

Kéver, L., Colleye, O., Lugli, M., Lecchini, D., Lerouvreur, F., Herrel, A. \& Parmentier, E. (2014a). Sound production in Onuxodon fowleri (Carapidae) and its amplification by the host shell. Journal of Experimental Biology 217, 4283-4294. doi: 10.1242/jeb.109363

Kéver, L., Boyle, K. S., Bolen, G., Dragičević, B., Dulčić, J. \& Parmentier, E. (2014b). Modifications in call characteristics and sonic apparatus morphology during puberty in Ophidion rochei (Actinopterygii: Ophidiidae). Journal of Morphology 275, 650-660.

Kéver, L., Boyle, K. S., Dragičević, B., Dulčić, J. \& Parmentier, E. (2014c). A superfast muscle in the complex sonic apparatus of Ophidion rochei (Ophidiiformes): histological and physiological approaches. Journal of Experimental Biology 217, 3432-3440.

Mann, D. \& Lobel, P. (1998). Acoustic behaviour of the damselfish Dascyllus albisella: behavioural and geographic variation. Environmental Biology of Fishes 51, 421-428.

Mann, D. A., Bowers-Altman, J. \& Rountree, R. A. (1997). Sounds produced by the striped cusk-eel Ophidion marginatum (Ophidiidae) during courtship and spawning. Copeia 1997, 610-612.

Matallanas, J. \& Riba, G. (1980). Aspectos biològicos de Ophidion barbatum Linnaeus, 1758 y O. rochei Müller, 1845 (Pisces, Ophidiidae) de la costa catalana. Investigacion Pesquera 44, 399-405.

Millot, S., Vandewalle, P. \& Parmentier, E. (2011). Sound production in red-bellied piranhas (Pygocentrus nattereri, Kner): an acoustical, behavioural and morphofunctional study. Journal of Experimental Biology 214, 3613-3618.

Nguyen, T. K., Hsung, L., Parmentier, E. \& Fine, M. L. (2008). Seasonal variation in sonic muscles in the fawn cusk-eel Lepophidium profundorum. Biology Letters 4, 707-710.

Nielsen, J. G., Cohen, D. M., Markle, D. F. \& Robins, C. R. (1999). FAO species catalogue 18: Ophidiiform fishes of the world (Order Ophidiiformes) - an annotated and illustrated catalogue of pearlfishes, cusk-eels, brotulas and other ophidiiform fishes known to date. FAO Fisheries Synopsis 125. Available at http://www.fao.org/docrep/009/x3930e/ x3930e00.htm

Papes, S. \& Ladich, F. (2011). Effects of temperature on sound production and auditory abilities in the striped raphael catfish Platydoras armatulus (Family Doradidae). PLoS One 6, e26479. doi: 10.1371/journal.pone.0026479 
Parmentier, E., Vandewalle, P. \& Lagardère, J.-P. (2003). Sound-producing mechanisms and recordings in Carapini species (Teleostei, Pisces). Journal of Comparative Physiology A 189, $283-292$.

Parmentier, E., Fine, M. L., Vandewalle, P., Ducamp, J.-J. \& Lagardère, J.-P. (2006). Sound production in two carapids (Carapus acus and C. mourlani) and through the sea cucumber tegument. Acta Zoologica (Stockholm) 87, 113-119.

Parmentier, E., Bouillac, G., Dragičević, B., Dulčić, J. \& Fine, M. L. (2010). Call properties and morphology of the sound-producing organ in Ophidion rochei (Ophidiidae). Journal of Experimental Biology 213, 3230-3236.

Rome, L. C. \& Lindstedt, S. L. (1998). The quest for speed: muscles built for high-frequency contractions. News in Physiological Sciences 13, 261-268.

Rose, J. A. (1961). Anatomy and sexual dimorphism of the swim bladder and vertebral column in Ophidion holbrooki (Pisces: Ophidiidae). Bulletin of Marine Science 11, 280-308.

Rowe, S. \& Hutchings, J. A. (2004). The function of sound production by Atlantic cod as inferred from patterns of variation in drumming muscle mass. Canadian Journal of Zoology 82, $1391-1398$.

Sprague, M. W. \& Luczkovich, J. J. (2001). Do striped cusk-eels Ophidion marginatum (Ophidiidae) produce the "chatter" sound attributed to weakfish Cynoscion regalis (Scianidae)? Copeia 2001, 854-859.

Templeman, W. \& Hodder, V. M. (1958). Variation with fish length, sex, stage of sexual maturity, and season in the appearance and volume of the drumming muscles of the swim-bladder in the haddock, Melanogrammus aeglefinus (L.). Journal of the Fisheries Research Board of Canada 15, 355-390.

Walker, T. J. (1975). Effects of temperature on rates in poikilotherm nervous systems: evidence from the calling songs of meadow katydids (Orthoptera: Tettigoniidae: Orchelimum) and reanalysis of published data. Journal of Comparative Physiology A 101, 57-69. 